\title{
BIOREMEDIATION OF OIL SHALE CHEMICAL INDUSTRY SOLID WASTES USING PHYTOREMEDITION AND BIOAUGMENTATION
}

\author{
Jaak Truu \\ Eeva Heinaru \\ Ene Talpsep \\ Eve Vedler \\ Marti Viirmäe \\ Liis Kärme \\ Ain Heinaru \\ Tartu University, Estonia
}

\begin{abstract}
Although the production of oil shale energy and oil has decreased steadily during the last years with a corresponding decrease in wastes, the semi-coke mounds constitute one of the major adverse environmental challenges in Estonia. The processed oil shale (semicoke) contains several organic and inorganic compounds (oil fractions, sulphides, phenolic compounds, polycyclic aromatic hydrocarbons). Laboratory and field experiments were carried out in order to test the effect of phytoremediation and bioaugmentation for remediation of pollutants in semi-coke. Four pilot test plots $\left(50 \mathrm{~m}^{2}\right)$ were established at semi-coke depository in July 2001. For bioaugmentation experiment the set of bacteria consisting of three biodegradative strains isolated from nearby area was selected. Several molecular microbiological methods were used to assess and compare the microbial community structure and diversity as well as the presence and diversity of biodegradative genes in collected samples. The dominant bacterial species based on 16S rDNA sequences in semi-coke samples were also identified. These analyses revealed that semi-coke microbial community is characterized by few dominant populations and possesses low diversity. The phytoremediation increased the number of bacteria and diversity of microbial community in semi-coke. Within a one and half year period starting from establishment of test plots, the concentration of phenolic compounds decreased up to $50 \%$ and oil products up to three times at plots with vegetation compared to control. Bioaugmentation experiment, performed in summer 2002 increased biodegradation intensity of oil products up to $50 \%$ compared to untreated planted controls. The plots, which were supplemented with laboratory-selected bacteria, were characterized by higher microbial activity and showed changes in microbial community structure. Our findings also indicate that plant growth; particularly rooting depth and
\end{abstract}


KALMAR ECO-TECH'03

Bioremediation and Leachate Treatment

KALMAR, SWEDEN, November 25-27, 2003

belowground biomass could be enhanced by adding mixture of selected bacterial strains to semi-coke.

\section{KEYWORDS}

Bioremediation; Bioaugmentation; Oil products; Oil shale chemical industry; Phenols, Phytoremediation.

\section{INTRODUCTION}

More than 70 years of oil shale thermal processing has resulted in huge dump sites of the coke ash (semi-coke) from semi-coking of oil shale in the areas surrounding oil shale chemical industry plants in northeastern part of Estonia. The semi-coke mounds cover an area about 200 ha and contain up to 70 million tons of solid waste. Currently, about 600 000 tons of processed semi-coke is disposed annually. Semi-coke solid wastes contain several organic and inorganic compounds (oil products, phenols, PAHs, sulfuric compounds), while liquid wastes (leachate) from depository area are characterized by high concentration of phenol, cresols, dimethylphenols and resorcinols. The liquid pollution from semi-coke dump area deteriorates surface water as well as the underlying aquifers [1].

Phytoremediation is an emerging technology based on the combined action of plants and their associated microbial communities to degrade, remove, inactivate or immobilize toxic compounds in soil. Plants may act directly accumulating (phytoaccumalution) and in some cases metabolising (phytodegradation) pollutants, but one way to achieve actually in situ bioremediation is by utilising plants to perform rhizosphere bioremediation (rhizodegradation or phytoremedition explanta) [2]. Vegetation facilitates bioremediation of contaminated soils due to root exudates that act as substrates for soil microorganisms, increasing in this way abundance and diversity of microbial community. Phytoremediation has been proposed as an efficient, low-cost remediation technique to restore areas contaminated with chlorinated solvents, BTEX compounds, phenols and PAHs.

Another possibility to achieve higher biodegradation rate of pollutants in soil is by introducing specific strains or microbial consortia. This approach, called bioaugmentation delivers to contaminated environment specific catabolic traits necessary for the clean up of pollutants [3].

The aim of current study is to assess the suitability of phytotechnological approach, which includes phytoremediation in combination with bioaugmentation for remediation of semi-coke dump area. 


\section{MATERIAL AND METHODS}

\section{KALMAR, SWEDEN, November 25-27, 2003}

\subsection{Phytoremediation experiment}

Four test plots (each $50 \mathrm{~m}^{2}$ ) were established at semi-coke depository in July 2001. Plant treatment was based on a grass mixture of four species. In addition to plants, four different treatments were utilized. The following treatments were applied: 1. plot - no treatment (grass seeds in semi-coke), 2. plot - seeds in semi-coke were covered by sand layer $(1-2 \mathrm{~cm}), 3$. plot- seeds in semi-coke were covered by peat layer $(1-2 \mathrm{~cm}), 4$. plot semi-coke was covered with the layer of pre-grown lawn. In October 2001 and 2002, the soil sampling was performed on plots and control area. We analyzed semi-coke samples collected from the test plots at the depository area for chemical and microbiological parameters.

\subsection{Bioaugmentation experiment}

For the bioaugmentation experiment the set of bacteria consisting of three strains isolated from nearby area was selected. These three bacterial strains Pseudomonas mendocina PC1, P. fluorescens PC24 and P. fluorescens PC18 degrade phenols via catechol meta, catechol or protocatechuate ortho or via the combination of catechol meta and protocatechuate ortho pathways, respectively [4]. In bioaugmentation experiments the biomass of these bacteria was supplied to the part experimental plots (each $10 \mathrm{~m}^{2}$ ) in July 2002. Each treatment received $20 \mathrm{~L}$ of bacterial suspension with concentration $10^{8} \mathrm{CFU}$ $\mathrm{ml}^{-1}$. The ratio of bacterial strains PC1, PC18 and PC24 was in suspension 3:1:1.

\subsection{Chemical analysis}

From each experimental plot pooled soil samples (20 subsamples) were collected with soil corer from two depths: $0-10 \mathrm{~cm}$ and $0-20 \mathrm{~cm}$, respectively. Oil products (extracted with pentane) were measured by gas chromatography. Volatile phenols were measured spectrophotometrically and by high-pressure liquid chromatography (HPLC). Total organic carbon was determined with infrared spectrophotometer. Chemical analyses were performed by Tartu Environmental Research, Ltd.

\subsection{Microbiological methods}

The microbial communities were removed from semi-coke and plant root surface by vortexing in sterile tap water. Heterotrophic plate count was enumerated by the spread plate method in triplicate on R2A agar (Difco). The number of phenol-degrading bacteria was determined in triplicate sets on M9-salts agar plates supplemented with trace elements and phenol $(2,5 \mathrm{mM})$. Agar plates were incubated at $228 \mathrm{C}$ for 1 week and the numbers of biodegradative bacteria were expressed as CFU (colony-forming units) per gram of dry soil. The heterotrophic activity and diversity of microbial community was measured using Biolog EcoPlates (Biolog, Inc.). Each well of the Biolog EcoPlates was inoculated by $150 \mu \mathrm{L}$ of extract $\left(10^{-2}\right.$ dilution) and the plates were incubated at $25^{\circ} \mathrm{C}$. Color development was measured every in $24 \mathrm{~h}$ for $120 \mathrm{~h}$ as absorbance at $590 \mathrm{~nm}$, with 
KALMAR ECO-TECH'03

Bioremediation and Leachate Treatment

KALMAR, SWEDEN, November 25-27, 2003

scanning spectrophotometer Multiscan 340C. Results of Biolog profiles were presented as total activity (summed absorbance of all 31 wells) and by Shannon diversity index.

\section{RESULTS}

Chemical properties of the semi-coke from experimental area are shown in the Table 1. After retorting at $500^{\circ} \mathrm{C}$, processed oil shale is highly saline, alkaline, biologically sterile, nutrient deficient material with no structure. According to ecotoxicological tests the fresh semi-coke is classified as of "high acute toxic hazard", whereas aged semi-coke is classified as of "acute toxic hazard" [5].

The chemical analysis of soil samples showed impact of the plant treatment on degradation rate of pollutants. Within a 16 months period starting from the establishment of test plots in July 2001, the concentration of volatile phenols was reduced by 30 to $50 \%$, the concentration of toil products nearly 3 times (from $310 \mathrm{mg} \mathrm{kg}^{-1}$ to $120 \mathrm{mg} \mathrm{kg}^{-1}$ ), and the total content of organic carbon decreased by 10 to $30 \mathrm{~g}$ per $\mathrm{kg}$ (from $18 \%$ to $15 \%$ ). The best results were obtained on the plots with peat amendment and pre-grown lawn with the highest root density in semi-coke. In upper layer samples $(0-10 \mathrm{~cm})$ the reduction of oil products and phenols was even bigger being in the range from $83 \%$ to $98 \%$.

Table 1. Chemical properties of semi-coke from the control plot.

\begin{tabular}{lc}
\hline Parameter & Measured value \\
\hline $\mathrm{pH}$ & $8.0-11.0$ \\
Total nitrogent(\%) & 0.08 \\
$\mathrm{P}-\mathrm{PO}_{4}{ }^{3-} \mathrm{mg} / \mathrm{kg}$ & 12.27 \\
$\mathrm{~K}^{+} \mathrm{mg} / \mathrm{kg}$ & 799.1 \\
$\mathrm{Ca}^{2+} \mathrm{mg} / \mathrm{kg}$ & \\
$\mathrm{Mg}^{2+} \mathrm{mg} / \mathrm{kg}$ & 826 \\
Total organic carbont(\%) & $18.0-18.0$ \\
Oil products mg/kg & $200-310$ \\
Volatile phenols mg/kg & $0.30-0 . .34$ \\
\hline
\end{tabular}

Bacterial biomass consisting of three bacterial strains was applied to three experimental plots in June 2002. Within a three months period the concentration of residual shale oil in semi-coke decreased by $13.6 \%$ to $53.6 \%$ at plots treated with bacterial biomass compared to untreated parts of experimental plots. The effect of bioaugmentation could be attributed either to activity of introduced bacterial strains or to horizontal transfer of biodegradative genes. The genetic information encoding degradation of pollutants is transferred from inoculated strains to indigenous bacterial populations by catabolic genetic elements. Introduced bacterial strains may also increase root biomass, length and/or exudation leading in this way to enhanced rhizosphere bioremediation. In our experiments we also observed the increase in root biomass and length on the plots amended with bacterial biomass, which in turn may led to enhanced rhizodegradation. 
KALMAR ECO-TECH'03

Bioremediation and Leachate Treatment

KALMAR, SWEDEN, November 25-27, 2003

From the semi-coke samples the number of aerobic heterotrophic and phenol- degrading bacteria was determined. The number of phenol-degrading bacteria increased by order of magnitude, while the number of heterotrophic aerobic bacteria remained on the same level compared to the untreated plot (see Table 2). Samples from the second year (2002) showed lower values of aerobic heterotrophic bacteria, which could be due to extremely dry vegetation period. The general trend was the increase of proportion of biodegradable bacterial numbers within microbial community due to the treatment. Highest values for all measured microbiological parameters were found in rhizosphere samples. While bacterial total numbers increased by order of magnitude compared to control, the number of phenol-degrading bacteria was more than 100 times higher in the rhizospheric soil. Addition of bacterial biomass to semi-coke resulted in increase both in absolute number (up to $7.8 \times 10^{6} \mathrm{CFU} \mathrm{\textrm {g } ^ { - 1 }}$ ) and relative abundance (up to $30 \%$ ) of phenol-degrading bacteria in the studied samples. The highest values for microbial activity and diversity measured with Biolog EcoPlates were recorded in rhizosphere samples.

Table 2. Abundance, diversity and metabolic activity of microbial communities from semi-coke experimental plots.

\begin{tabular}{lcccc}
\hline Plot / sample & $\begin{array}{c}\text { Aerobic } \\
\text { heterotrophic } \\
\text { bacteria } \\
\text { (CFU/g) }\end{array}$ & $\begin{array}{c}\text { Phenol } \\
\text { degrading } \\
\text { bacteria } \\
\text { (CFU/g) }\end{array}$ & $\begin{array}{c}\text { Shannon } \\
\text { diversity }\end{array}$ & $\begin{array}{c}\text { Metabolic } \\
\text { activity } \\
\text { (OD/g) }\end{array}$ \\
\hline Control & $1.0 \times 10^{7}$ & $1.6 \times 10^{4}$ & 3.2 & 1.7 \\
Only grass & $1.0 \times 10^{7}$ & $1.6 \times 10^{5}$ & 4.1 & 5.1 \\
Grass and sand & $6.3 \times 10^{6}$ & $1.7 \times 10^{5}$ & 3.3 & 3.1 \\
Grass and peat & $8.4 \times 10^{6}$ & $3.5 \times 10^{5}$ & 4.5 & 6.6 \\
Grass and peat / rhizospere & $9.2 \times 10^{7}$ & $3.3 \times 10^{6}$ & 4.5 & 9.7 \\
Pre-grown lawn & $8.3 \times 10^{6}$ & $1.8 \times 10^{5}$ & 3.9 & 5.2 \\
$\begin{array}{l}\text { Pre-grown lawn / } \\
\text { rhizospere }\end{array}$ & $5.7 \times 10^{7}$ & $1.2 \times 10^{6}$ & 4.5 & 11.6 \\
\hline
\end{tabular}

From four tested grass species Lolim perenne (perennial ryegrass), Poa pratensis (Kentucky bluegrass) and Festuca rubra (red fescue) were found growing on plots. The growth rate of plants was approximately twice higher in the case of peat and sand amendments. The mechanism of phytoremediation systems, based on rhizodegradation, is increase in microbial numbers and activity as well as altered microbial community functional structure due to nutrient release by plants. This scenario has been suggested by many researchers $[6,7,8]$. Our data suggest that establishment of plants promoted increase of biodegradative bacterial number in semi-coke, especially in the vicinity of roots.

\section{CONCLUSIONS}

Our results indicate that phytoremediation and bioaugmentation could be considered as an alternative management option for remediation of oil shale solid waste. Additional beneficial side effects of the establishment of vegetation on the semi-coke deposit are 
KALMAR ECO-TECH'03

Bioremediation and Leachate Treatment

KALMAR, SWEDEN, November 25-27, 2003

reduction of leachate amount and toxicity, and surface erosion. Also, plant cover would diminish the dispersion of pollutants into adjacent area including Kohtla-Järve city by air. When semi-coke toxicity is decreased, it becomes more suitable substrate for trees, as mycorrhizal fungi of tree roots are more sensitive to pollutants compared to bacteria. The better growth of trees in turn favors the remediation of deeper layers of semi-coke as well stabilizes the soil structure. Our findings support the prospect to use integrated environmental biotechnology approach for remediation of semi-coke dump area. The goals of integrated approach could be achieved through sequential application of phytotechnology, bioaugmentation, composting of semi-coke for creating soil amendment on site and constructed wetlands. Constructed wetlands decrease the amount of recalcitrant pollutants in leachate and reduce the load of wastewater to local water treatment plant.

\section{ACKNOWLEDGEMENTS}

The study was funded by the Maj and Tor Nessling Foundation and partly by the Estonian Science Foundation grant No 4344 .

\section{REFERENCES}

[1] Truu, J., Heinaru, E., Talpsep, E., Heinaru, A., 2002. Analysis of River pollution Data from Low-Flow Period by Means of Multivariate Techniques: A Case Study from the Oil-Shale Industry Region, Northeastern Estonia. Environmental Science and Pollution Research 1, 8-14.

[2] Romantschuk M., Sarand I., Petänen T., Peltola R., Jonsson-Vihanne M., Koivula T., Yrjälä K., Haahtela K., 2000. Means to improve the effect of on situ bioremediation of contaminated soil: an overview of novel approaches. Environmental Pollution, 107, 179-185. DO1: https://doi.org/10.1016/S0269-7491(99)00136-0

[3] Top, E., Springael, D., Boon, N., 2002. Catabolic mobile genetic elements and their potential use in bioaugmentation of polluted soils and waters. FEMS Microbiology Ecology, 42, 199-208. DO1: https://doi.org/10.1111/j.1574-6941.2002.tb01009.x

[4] Heinaru, E, Truu, J., Stottmeister, U., Heinaru, A., 2000. Three types of phenol and p-cresol catabolism in phenol- and p-cresol-degrading bacteria isolated from river water continuously polluted with phenolic compounds. FEMS Microbiology Ecology, 31, 195-205. DO1: https://doi.org/10.1111/j.1574-6941.2000.tb00684.x

[5] Põllumaa, L., Maloveryan, A., Trapido, M., Sillak, H., Kahru, A., 2001. A study of the environmental hazard caused by the oil shale industry solid waste. ATLA, 29, 259-267.

[6] Haby, P., Crowley, D., 1996. Biodegradation of 3-chlorobenzoate as affected by rhizodeposition and selected carbon substrates. J. Environ. Qual., 25, 304-310.

DO1: https://doi.org/10.2134/jeq1996.00472425002500020014x 
KALMAR ECO-TECH'03

Bioremediation and Leachate Treatment

KALMAR, SWEDEN, November 25-27, 2003

[7] Joner, E., Corgie, S., Amellal, N, Leyval, L., 2002. Nutritional constraints to degradation of polycyclic aromatic hydrocarbons in a simulated rhizosphere. Soil Biol Biochem., 34, 859-864.

[8] Siciliano, S., Germida, J., Banks, K., Greer, C., 2003. Changes in microbial community composition and function during a polyaromatic hydrocarbon phytoremediation field trial. Applied and Environmental Microbiology, 69, 1, 483489. 